\title{
Lymphoepithelioma-like carcinoma of the urinary tract: a clinicopathological study of 30 pure and mixed cases
}

\author{
Ecaterina F Tamas ${ }^{1}$, Matthew E Nielsen², Mark P Schoenberg ${ }^{2}$ and Jonathan I Epstein ${ }^{1,2,3}$ \\ ${ }^{1}$ Department of Pathology, Johns Hopkins Hospital, Baltimore, MD, USA; ${ }^{2}$ Department of Urology, Johns \\ Hopkins Hospital, Baltimore, MD, USA and ${ }^{3}$ Department of Oncology, Johns Hopkins Hospital, Baltimore, \\ $M D, U S A$
}

\begin{abstract}
We studied 28 cases of lymphoepithelioma-like carcinoma of the bladder, one case in the renal pelvis, and one in the urethra. The mean age of the patients was 67.6 years with $21(70 \%)$ males. Seventeen cases $(56.7 \%)$ were pure with the remaining mixed with other patterns of carcinoma, including invasive urothelial carcinoma $(n=10)$, invasive adenocarcinoma $(n=3)$, and squamous cell carcinoma $(n=2)$. The surface demonstrated carcinoma in situ (CIS) in six cases, noninvasive high-grade papillary urothelial carcinoma in three cases, and in situ adenocarcinoma in one case. In 19/30 (66\%) cases, there was a heavy lymphocytic infiltrate and in the remaining $11 / 30(34 \%)$ cases a mixed inflammatory infiltrate. None of the 26 cases labeled for EBV-encoded RNA by in situ hybridization. Tumor stages at presentation were: seven cases T1 (23\%); 14 cases T2 (47\%); seven cases T3 (23\%); and two cases T4 (7\%). Treatment consisted of radical cystectomy in 13/30 cases (43\%); partial cystectomy in 4/30 cases (13\%); nephrectomy in one case (3\%), and transurethral resection often followed by radiation or chemotherapy in $12 / 30(40 \%)$ cases. The mean follow up for patients without progression was 31 months. Eight of 27 cases with follow-up $(30 \%)$ cases had tumor recurrence, with seven patients having metastases. In cases treated with cystectomy, the 5-year actuarial recurrence-free risk was $59 \%$ (62 and $57 \%$, for pure and mixed cases, respectively). Lymphoepithelioma-like carcinoma, whether in pure or mixed form, has a similar prognosis to ordinary urothelial carcinoma when treated by cystectomy. Of the three pure cases treated by chemotherapy, two were free of disease at 4 and 65 months and the third had recurrent disease at 17 months. Given the association of lymphoepithelioma-like carcinoma with urothelial carcinoma in $47 \%$ of our cases and its propensity for multifocality, partial cystectomy would typically be ill advised for lymphoepithelioma-like carcinoma.

Modern Pathology (2007) 20, 828-834; doi:10.1038/modpathol.3800823; published online 1 June 2007
\end{abstract}

Keywords: lymphoepithelioma; lymphoepithelioma-like; urothelial carcinoma; EBV encoded RNA; EBER

Lymphoepithelioma is a form of undifferentiated carcinoma primarily described in the nasopharynx in Asian patients. In this location, there is a close pathogenetic link of carcinoma to Epstein-Barr virus (EBV). Carcinomas with similar histological features arising outside the nasopharynx are called lymphoepithelioma-like carcinoma. Lymphoepithelioma-like carcinoma has been described in a variety of organs including salivary glands, thymus, lung, skin, stomach, uterine cervix, breast, prostate, and the urinary tract. ${ }^{1-15}$

In the urinary tract, they typically arise in the urinary bladder, although isolated cases have been

Correspondence: Dr JI Epstein, MD, Department of Pathology, Johns Hopkins Hospital, 401 N Broadway Street, Room 2242, Weinberg Building, Baltimore, MD 21231, USA.

E-mail: jepstein@jhmi.edu

Received 9 February 2007; revised 2 April 2007; accepted 3 April 2007; published online 1 June 2007 reported in the renal pelvis, ureter, and urethra., Lymphoepithelioma-like carcinoma of the urinary bladder, first reported by Zuckerberg et al in 1991, is uncommon with a reported incidence between 0.4 and $1.3 \%$ of all bladder carcinomas. ${ }^{12}$ Prior to the current series, the largest report in the literature was a study of 13 cases by Lopez-Beltran et al. ${ }^{11}$ Although it has been suggested that lymphoepithelioma-like carcinoma of the bladder is associated with a more favorable prognosis compared to conventional invasive urothelial carcinoma, there have been relatively few small studies on lymphoepithelioma-like carcinoma in the literature to date. ${ }^{1,5,8,12}$

\section{Materials and methods}

Thirty cases of lymphoepithelioma-like carcinoma arising in the urinary tract were retrieved from the 
consultation files of one of the authors and the archival files of Surgical Pathology at The Johns Hopkins Hospital between 1990 and 2005 (16 consults and 14 in-house cases). Lymphoepithelioma-like carcinoma was classified as pure when $100 \%$ of the tumor showed lymphoepithelioma-like carcinoma pattern, and mixed when associated with usual infiltrating urothelial carcinoma, adenocarcinoma, or squamous carcinoma. There were two cases that were still considered pure lymphoepithelioma-like carcinoma despite having rare foci of atypical morphology (see Results).

Clinical follow up was possible in all cases, however 3/30 were recent cases with short followup. Time to tumor recurrence was measured from the date of cystectomy or in cases without cystectomy from the date of the diagnostic tissue sampling. Recurrence-free survival risks were evaluated using Cox regression analysis (Stata, College Station, TX, USA).

Immunohistochemical stains for cytokeratin AE1/ AE3 (Clone AE1/AE3 + PCK26, Ventana) and EBVencoded RNA (EBER) in situ hybridization (EpsteinBarr Virus Probe, fluorescein conjugated, Vector Laboratories) were performed based on availability of the blank slides.

\section{Results}

The mean age of the patients was 67.6 years (range: 44-90 years) with 21 (70\%) males. The mean follow up for patients without progression was 32 months (median: 34 months). The location of the tumor was in the urinary bladder with the exception of one case located in the renal pelvis and one case located in the urethra.

Seventeen cases $(57 \%)$ had pure lymphoepithelioma-like carcinoma with the remaining cases having lymphoepithelioma-like carcinoma with other patterns of carcinoma (Table 1). The epithelial component of lymphoepithelioma-like carcinoma consisted of nests and individual cells of undifferentiated carcinoma admixed with a prominent often-obscuring inflammatory infiltrate (Figures $1-3)$. In two cases, $<1 \%$ of the tumor had glandular differentiation in an otherwise typical lymphoepithelioma-like carcinoma, where the glandular element merged with the typical lymphoepithelioma-like carcinoma and the glandular elements were heavily infiltrated by lymphocytes identical to typical lymphoepithelioma-like carcinoma and in contrast to adenocarcinoma associated with lymphocytes (Figure 4). In two other cases, the epithelial component of lymphoepithelioma-like carcinoma was focally composed of clear cells (Figure 5). Of the 13 cases without pure lymphoepitheliomalike carcinoma, the associated conventional carcinoma component was invasive urothelial carcinoma $(n=10)$, invasive adenocarcinoma $(n=3)$, and squamous cell carcinoma $(n=2)$ (some tumors with more than one non-lymphoepithelioma-like carcinoma component). In addition to lymphoepithelioma-like carcinoma, the surface demonstrated carcinoma in situ (CIS) in six cases, noninvasive high-grade papillary urothelial carcinoma in three cases, and in situ adenocarcinoma in one case (Figures 6 and 7). Either invasive or noninvasive urothelial carcinoma was associated with lymphoepithelioma-like carcinoma in $14 / 30(47 \%)$ cases (Table 1). In 19/30 $(66 \%)$ cases, the inflammatory component consisted of a heavy lymphocytic infiltrate and in the remaining $11 / 30(34 \%)$ cases a mixed inflammatory infiltrate composed of neutrophils, eosinophils, lymphocytes, histiocytes, and plasma cells (Figures 1 and 8).

All 28 cases studied expressed strong cytoplasmic positivity for cytokeratin AE1/AE3 (Figure 9). None of the 26 cases studied showed any labeling for EBER by in situ hybridization.

Tumor stages were as follows: seven cases T1 (23\%); 14 cases T2 (47\%); seven cases T3 (23\%); and two cases T4 (7\%) (Table 1). Treatment consisted of cystoprostatectomy in $10 / 30$ cases $(33 \%)$; radical cystectomy in $3 / 30$ cases $(10 \%)$; partial cystectomy in $4 / 30$ cases (13\%); nephrectomy in one case (3\%), and transurethral resection (TUR) often followed by radiation or chemotherapy in $12 / 30(40 \%)$ cases. All together, eight of 27 cases with follow-up (30\%) cases had recurrence of tumor. Of the 27 patients, seven $(26 \%)$ patients had metastases: three cases had lymph node metastasis and four cases had distant metastasis (lung $(n=2)$; abdomen; skin, lymph nodes). The overall 5-year actuarial recurrence-free risk was $69 \%$ (74 and $64 \%$ for pure and mixed lymphoepithelioma-like carcinoma, respectively). In cases treated with cystectomy, the overall 5 -year actuarial recurrence-free risk was 59\% (62 and $57 \%$, for pure and mixed lymphoepitheliomalike carcinoma, respectively).

\section{Discussion}

Lymphoepithelioma was originally described in the nasopharynx in Asian patients and was tightly associated with Epstein-Barr virus. ${ }^{1,11,12,16-18}$ The EBV-encoded RNA (EBER) is abundantly expressed in latently infected cells and in the malignant epithelial cells of nasopharyngeal carcinoma. The function of EBER is still uncertain, but EBER transcripts provide a convenient marker of tumorassociated viral infection. In the nasopharynx, there is a strong association between p53 overexpression and EBER status, and EBV-infected tumors are prone to show an undifferentiated histology. ${ }^{16}$

Similar morphological lesions have been reported in the salivary glands, thymus, lung, skin, stomach, breast, genitourinary tract, and other organs. ${ }^{1-15}$ Besides nasopharyngeal carcinoma, EBV is frequently found in carcinomas arising in the lung, stomach, thymus, and salivary gland, but not in 
Table 1 Clinicopathological correlation

\begin{tabular}{|c|c|c|c|c|}
\hline Case & LELC histology & $\begin{array}{l}\text { Non-LELC } \\
\text { histology }\end{array}$ & $\begin{array}{l}\text { Stage } \\
\text { at Dx }\end{array}$ & Treatment and prognosis \\
\hline 1 & Mixed & $\mathrm{Sq}$ & T3No & $\begin{array}{l}\text { TUR, CP } \\
\text { NED ( } 55 \text { months) }\end{array}$ \\
\hline 2 & Mixed & $\mathrm{UC}, \mathrm{Sq}$ & $\mathrm{T} 2$ & $\begin{array}{l}\text { TUR, XRT, Chemo. } \\
\text { NED ( } 24 \text { months) }\end{array}$ \\
\hline 3 & Pure & & T3N1 & $\begin{array}{l}\text { TUR, PC } \\
\text { Lung mets ( } 23 \text { months) }\end{array}$ \\
\hline 4 & $\begin{array}{l}\text { Pure (rare glands with } \\
\text { LELC morphology) }\end{array}$ & & T2No & $\begin{array}{l}\text { TUR, CP } \\
\text { NED ( } 40 \text { months) }\end{array}$ \\
\hline 5 & Pure & CIS & $\mathrm{T} 4 \mathrm{~N} 1$ & $\begin{array}{l}\text { TUR, RC } \\
\text { Pelvic recurrence ( } 24 \text { months) } \\
\text { XRT, NED ( } 36 \text { months) }\end{array}$ \\
\hline 6 & Pure & & T3No & $\begin{array}{l}\text { TUR, CP } \\
\text { NED ( } 42 \text { months) }\end{array}$ \\
\hline 7 & Pure & HGUC & T2No & $\begin{array}{l}\text { TUR, CP } \\
\text { NED ( } 46 \text { months) }\end{array}$ \\
\hline 8 & Pure & & $\mathrm{T} 2 \mathrm{~N} 1$ & $\begin{array}{l}\text { TUR, PC } \\
\text { TUR } \times 2 \text { (110, } 129 \text { months) } \\
\text { Sarcomatoid carcinoma (135 months) Chemo., } \\
\text { XRT NED (159 months) }\end{array}$ \\
\hline 9 & Mixed & CIS, Sq, UC & $\mathrm{T} 3 \mathrm{Nx}$ & $\begin{array}{l}\text { RN, Chemo. } \\
\text { NED ( } 34 \text { months) }\end{array}$ \\
\hline 10 & $\begin{array}{l}\text { Pure (rare glands with } \\
\text { LELC morphology) }\end{array}$ & & T4No & $\begin{array}{l}\text { RC, Chemo. } \\
\text { NED ( } 29 \text { months) }\end{array}$ \\
\hline 11 & Pure & & T3N0 & $\begin{array}{l}\text { TUR, CP } \\
\text { NED ( } 23 \text { months) }\end{array}$ \\
\hline 12 & Pure & & T2No & $\begin{array}{l}\text { TUR, CP } \\
\text { Death by other causes ( } 3 \text { months) }\end{array}$ \\
\hline 13 & $\begin{array}{l}\text { Pure with focal clear cell } \\
\text { features }\end{array}$ & & $\mathrm{T} 2$ & $\begin{array}{l}\text { TUR, Chemo., } \\
\text { XRT TUR ( } 17 \text { months) }\end{array}$ \\
\hline 14 & Mixed & HGUC; UC & $\mathrm{T} 2$ & $\begin{array}{l}\text { TUR, PC } \\
\text { NED (10 months) }\end{array}$ \\
\hline 15 & Pure & HGUC; CIS & $\mathrm{T} 2$ & $\begin{array}{l}\text { TUR, Thermal, Chemo. } \\
\text { NED ( } 4 \text { months) }\end{array}$ \\
\hline 16 & Mixed & UC & $\mathrm{T} 2$ & $\begin{array}{l}\text { TUR (refused treatment) } \\
\text { Abdominal spread ( } 4 \text { months) }\end{array}$ \\
\hline 17 & Pure & & $\mathrm{T} 1$ & $\begin{array}{l}\text { TUR, XRT } \\
\text { NED ( } 6 \text { months) }\end{array}$ \\
\hline 18 & Mixed & Adeno & $\mathrm{T} 1$ & $\begin{array}{l}\text { TUR, Chemo. } \\
\text { NED ( } 6 \text { months) }\end{array}$ \\
\hline 19 & $\begin{array}{l}\text { Pure with focal } \\
\text { clear cell features }\end{array}$ & & T3No & $\begin{array}{l}\text { TUR, CP } \\
\text { NED (4 months) }\end{array}$ \\
\hline 20 & Mixed & UC & $\mathrm{T} 1$ & $\begin{array}{l}\text { TUR } \\
\text { Death by other causes ( } 42 \text { months) }\end{array}$ \\
\hline 21 & Pure & & $\mathrm{T} 2$ & $\begin{array}{l}\text { TUR, XRT, Chemo. } \\
\text { Death by other causes ( } 65 \text { months) }\end{array}$ \\
\hline 22 & Mixed & UC CIS & T1No & $\begin{array}{l}\text { TUR, CP } \\
\text { NED ( } 9 \text { months) }\end{array}$ \\
\hline 23 & Pure & & $\mathrm{T} 1$ & $\begin{array}{l}\text { TUR, BCG } \\
\text { NED ( } 38 \text { months) }\end{array}$ \\
\hline 24 & Pure & CIS & $\mathrm{T} 1$ & $\begin{array}{l}\text { TUR } \\
\text { Death by other causes ( } 48 \text { months) }\end{array}$ \\
\hline 25 & Pure & & T2No & $\begin{array}{l}\text { TUR, CP } \\
\text { Recent case, short follow-up }\end{array}$ \\
\hline 26 & Mixed & UC & $\mathrm{T} 2$ & $\begin{array}{l}\text { TUR, Chemo. } \\
\text { Recent case, short follow-up }\end{array}$ \\
\hline 27 & Mixed & Adeno & $\mathrm{T} 2$ & $\begin{array}{l}\text { TUR, } \\
\text { Retroperitoneal and pelvic node mets. and pelvic } \\
\text { tumor ( } 5 \text { months) } \\
\text { XRT and Chemo. (progression at } 8 \text { months) }\end{array}$ \\
\hline 28 & Mixed & CIS, UC & T1No & $\begin{array}{l}\text { TUR, CP } \\
\text { Lungs mets. ( } 5 \text { months) } \\
\text { Death by of disease ( } 18 \text { months) }\end{array}$ \\
\hline 29 & Mixed & UC & T3N1 & $\begin{array}{l}\text { TUR, RC } \\
\text { Skin mets. ( } 5 \text { months) }\end{array}$ \\
\hline 30 & Mixed & AIS; Adeno UC & $\mathrm{T} 2$ & $\begin{array}{l}\text { TUR, PC } \\
\text { Recent case, short follow-up }\end{array}$ \\
\hline
\end{tabular}

Abbreviations: CP, cystoprostatectomy; RC, radical cystectomy; PC, partial cystectomy; RN, right nephrectomy; CIS, flat carcinoma in situ; HGUC, noninvasive high grade papillary urothelial carcinoma; UC, invasive urothelial carcinoma; Adeno, invasive adenocarcinoma; AIS, in situ adenocarcinoma; Sq, invasive squamous cell carcinoma; TUR, transurethral resection; XRT, radiotherapy; Chemo, chemotherapy; NED, no evidence of disease; Met, metastasis; DX, diagnosis. 

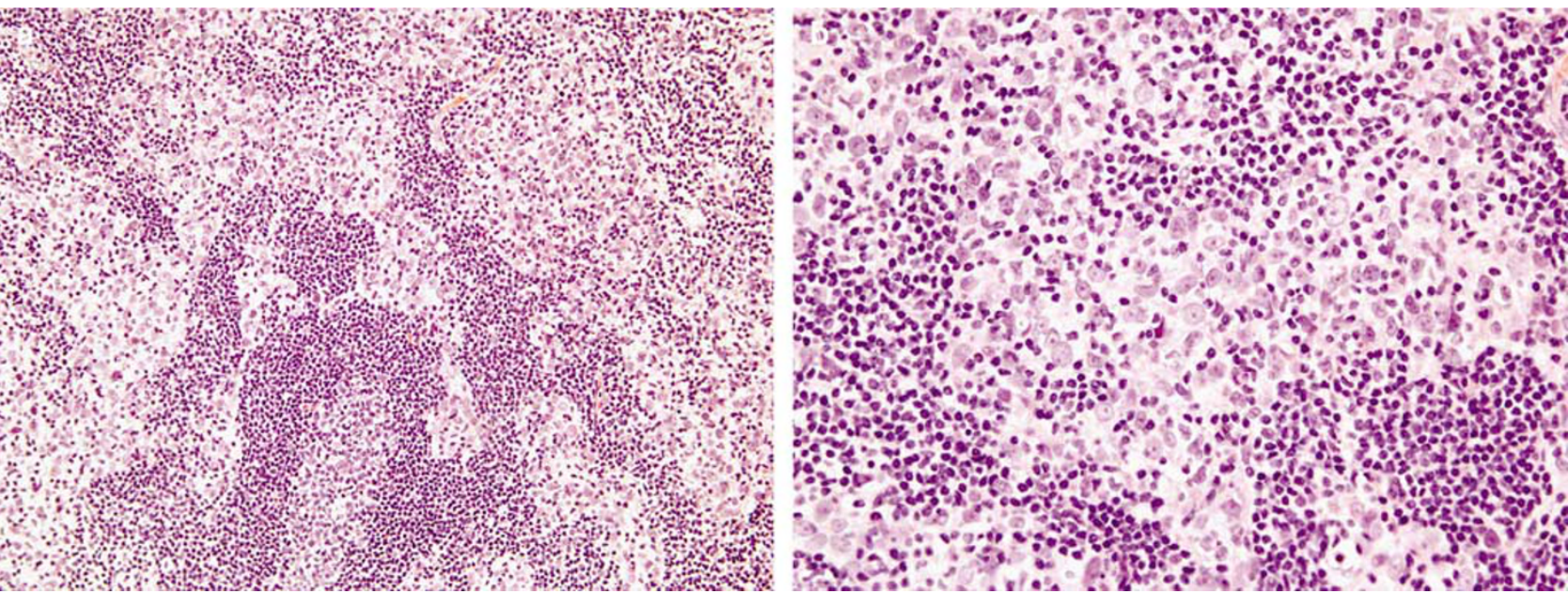

Figure 1 Lymphoepithelioma-like carcinoma, syncytial pattern with prominent lymphocytic infiltrate.

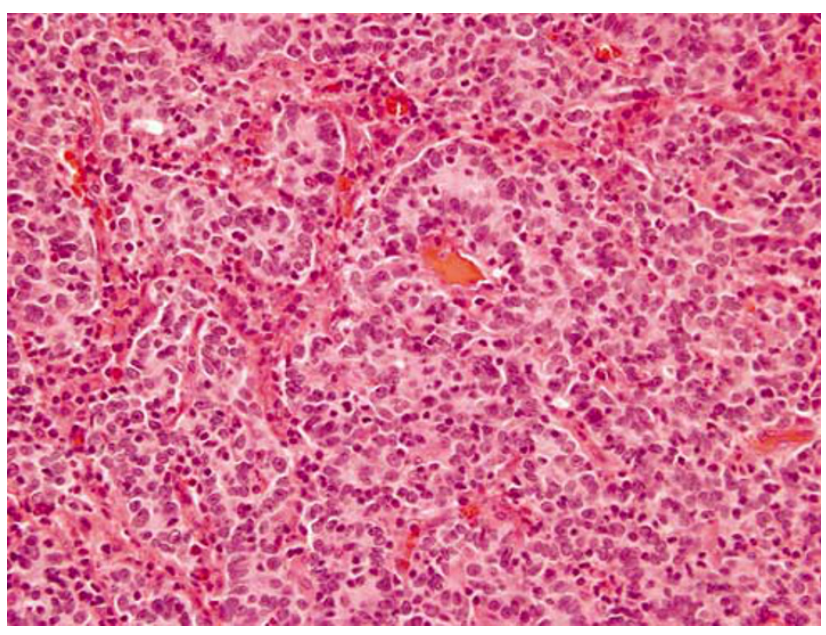

Figure 2 Lymphoepithelioma-like carcinoma with cords of cells associated with a prominent inflammatory infiltrate.

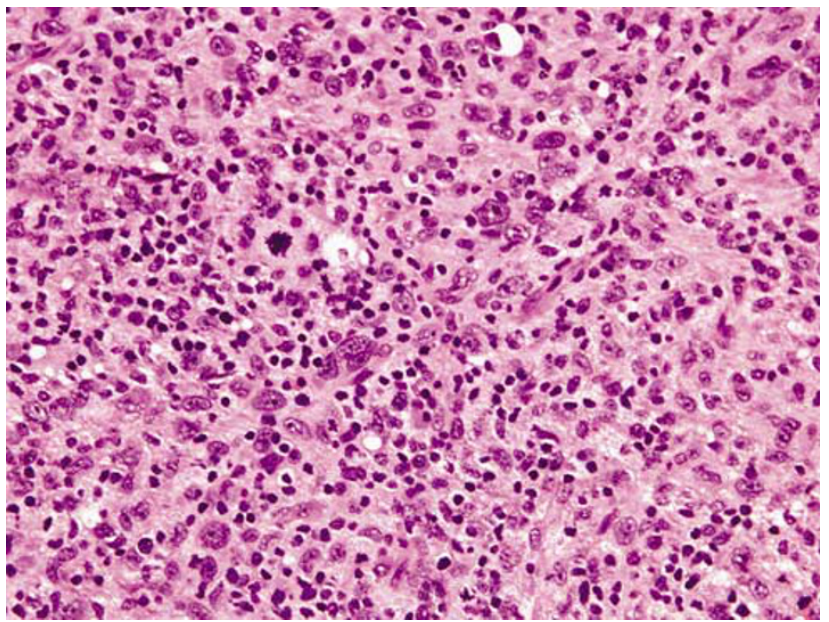

Figure 3 Lymphoepithelioma-like carcinoma with individual undifferentiated tumor cells admixed with inflammation.

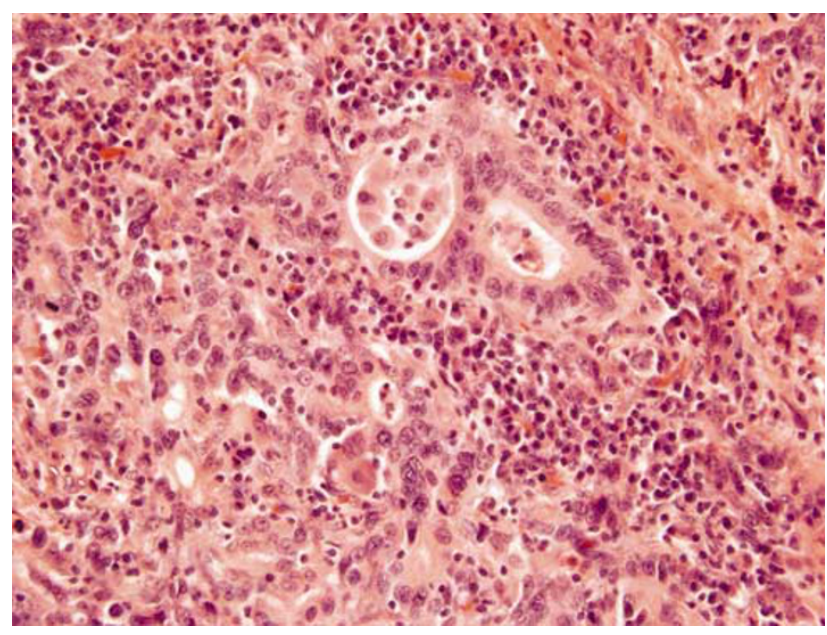

Figure 4 Lymphoepithelioma-like carcinoma with rare glandular features.

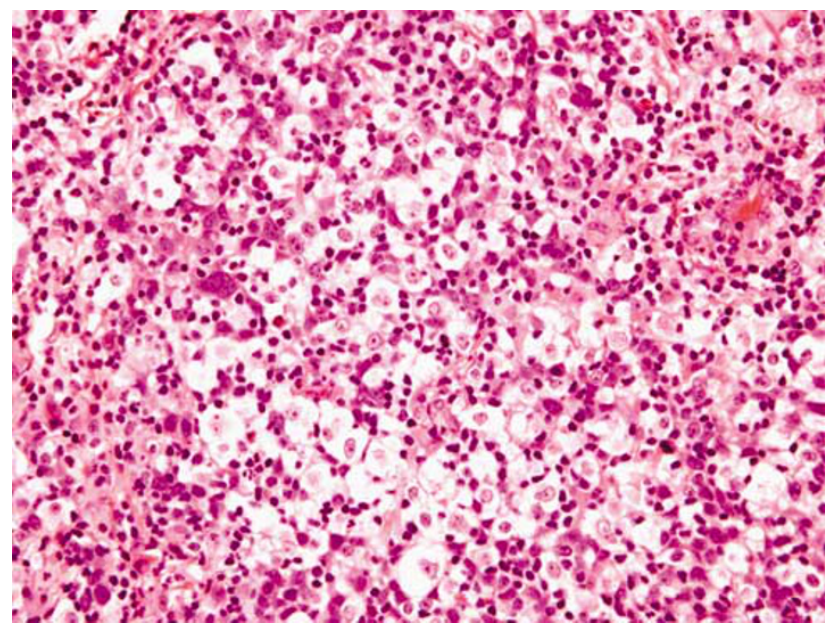

Figure 5 Lymphoepithelioma-like carcinoma with focal clear cell features. 


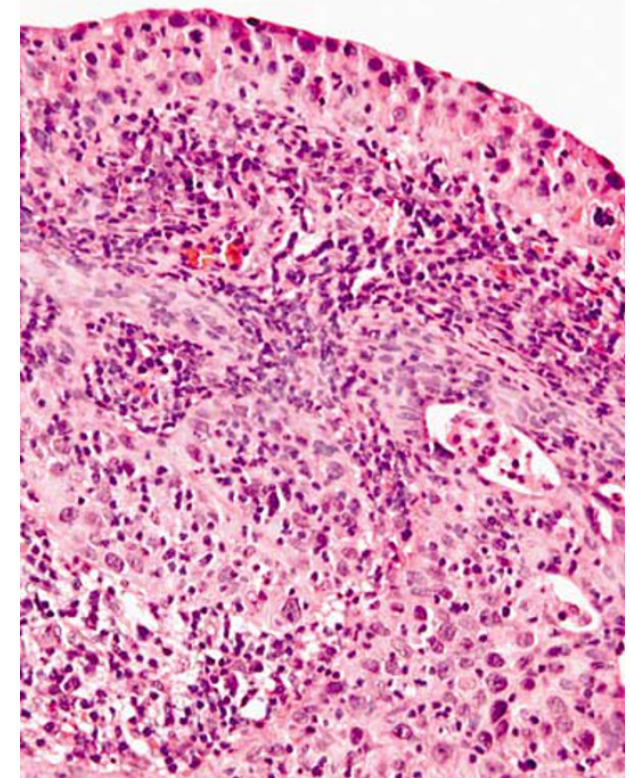

Figure 6 CIS overlying lymphoepithelioma-like carcinoma.

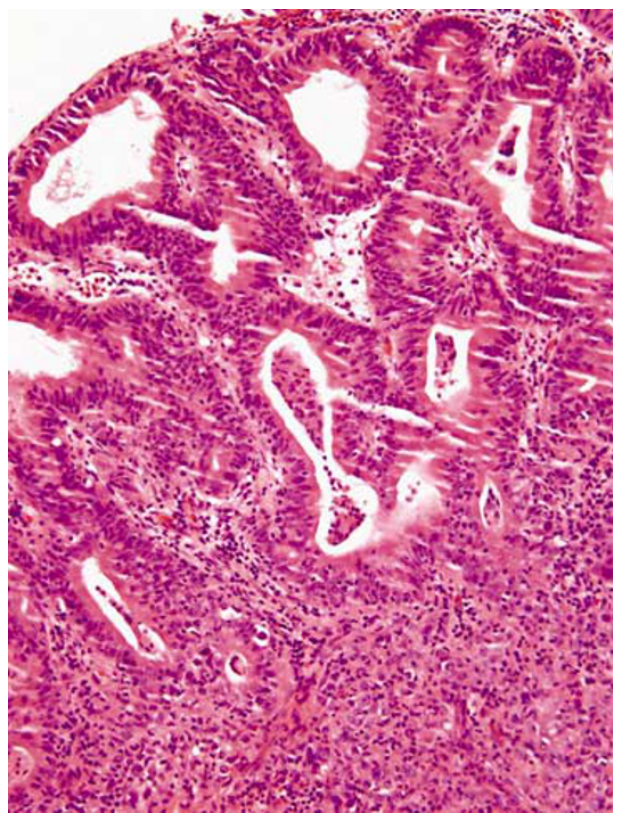

Figure 7 In situ adenocarcinoma overlying lymphoepitheliomalike carcinoma.

other locations..$^{2,4,6,7,9,13,15,16}$ These data confirm that EBV is not a prerequisite for development of lymphoepithelioma-like carcinoma. None of our cases showed any labeling for EBER by in situ hybridization. This is in concordance with data in the literature showing no relation of the EBV to lymphoepithelioma-like carcinoma of the urinary tract. ${ }^{1,3,5,7,8,11,12,16}$ It appears that abnormalities of p53 regulation are crucial in development of the

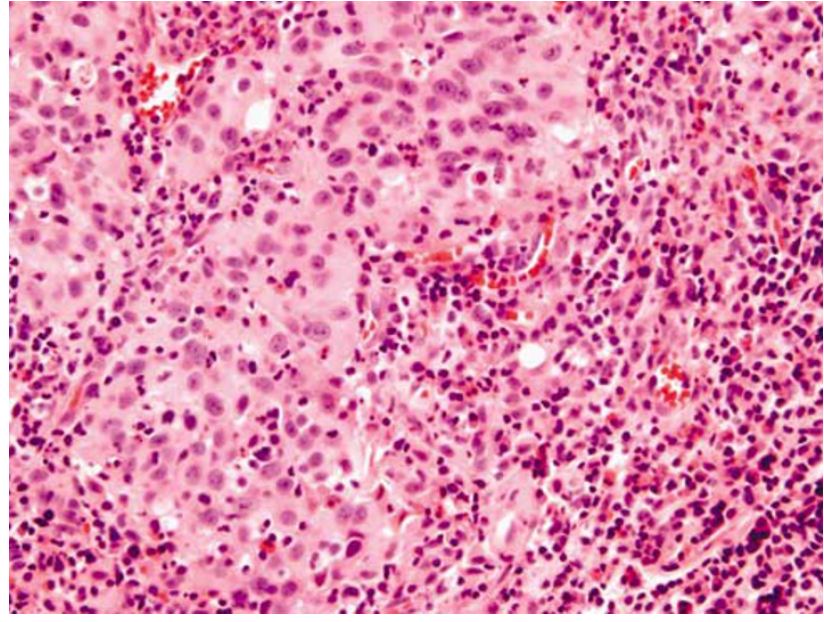

Figure 8 Lymphoepithelioma-like carcinoma with mixed inflammatory infiltrate.

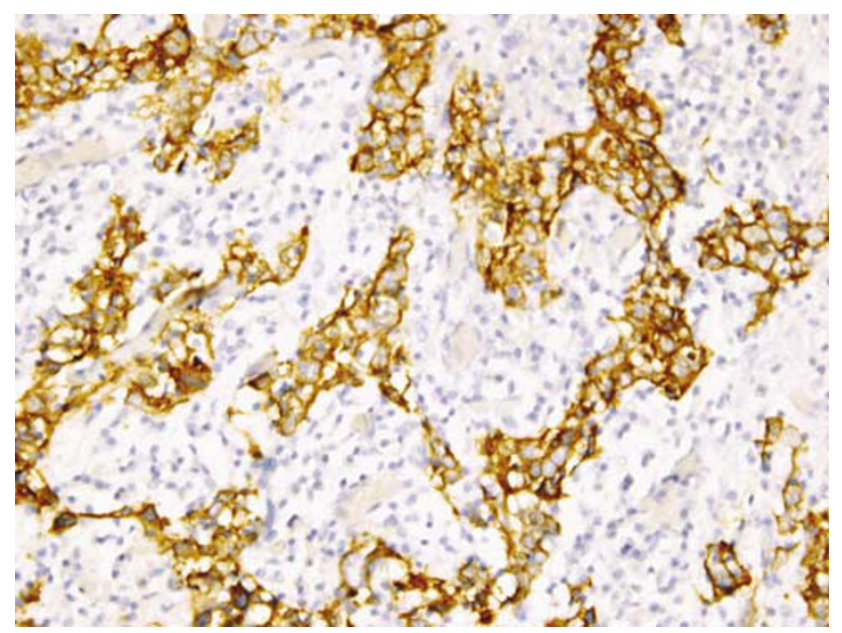

Figure 9 Strong cytoplasmic staining with cytokeratin AE1/AE3 in lymphoepithelioma-like carcinoma.

lymphoepithelioma-like carcinoma of the urinary tract. ${ }^{8,17-19}$

Only a few relatively large series of lymphoepithelioma-like carcinoma have been reported in the urinary bladder. ${ }^{1,3,7-9,11,12}$ In the current study, we had 17 pure and 13 mixed lymphoepitheliomalike carcinoma cases. The largest series of genitourinary lymphoepithelioma-like carcinoma (13 cases) prior to the current one contained three pure, six predominant, and four focal lymphoepitheliomalike carcinomas. ${ }^{11}$ In the other two relatively large series, Amin et $a l^{1}$ reported three pure, five predominant, and three focal lymphoepitheliomalike carcinomas and Holmang et $a l^{7}$ studied three pure, five predominant, and three focal cases of lymphoepithelioma-like carcinoma. Although the epithelial pattern in lymphoepithelioma-like carcinoma is undifferentiated, this is the first series to specifically note rare glandular and clear cell differentiation associated with a heavy inflammatory infiltrate as part of the epithelial component of 
lymphoepithelioma-like carcinoma. Other reports have described lymphoepithelioma-like carcinoma with adenocarcinoma or squamous carcinoma, yet in these cases the description appears to be those of conventional adenocarcinoma or squamous cell carcinoma coexisting with a predominant or focal lymphoepithelioma-like carcinoma. ${ }^{11,12}$ It is controversial whether the two cases in the current study with rare glandular elements represent pure lymphoepithelioma-like carcinoma. However, the glandular areas differed from conventional adenocarcinoma with an associated inflammatory component. First, the foci were extremely rare in an otherwise classic lymphoepithelioma-like carcinoma such that it does not seem correct to combine these cases with the mixed cases with significant areas of usual adenocarcinoma. Secondly, the cytological features of the cells with focal glandular features were identical to the adjacent undifferentiated carcinoma. Third, the rare glands were intimately infiltrated by a dense lymphocytic infiltrate in an identical fashion to surrounding lymphoepithelioma-like carcinoma, differing from other cases in our series where differentiated components either lacked a lymphocytic infiltrate or the infiltrate was in the stroma adjacent to the epithelium rather than intimately intermingled.

The overlying urothelium in lymphoepitheliomalike carcinoma may show urothelial dysplasia, carcinoma in situ, noninvasive or invasive urothelial carcinoma or even adenocarcinoma in situ. Owing to the prominent inflammatory background, lymphoepithelioma-like carcinoma can be misdiagnosed either as a reactive inflammatory lesion or lymphoma. ${ }^{1,12}$ Immunohistochemistry for keratins and lymphoid markers can resolve this differential diagnosis. All 28 of our cases stained for AE1/AE3 showed strong cytoplasmic positivity supporting the diagnosis of carcinoma.

One of the conclusions of previous smaller studies is that pure or pure/predominant lymphoepithelioma-like carcinoma has a better prognosis than focal lymphoepithelioma-like carcinoma. ${ }^{1,5,11,12}$ In the study by Lopez-Beltran et $a{ }^{11}{ }^{11}$ all three patients with pure and 4/6 patients with predominant lymphoepithelioma-like carcinoma were alive, while all four patients having focal lymphoepithelioma-like carcinoma died of disease. Amin et al reported on three patients having pure lymphoepithelioma-like carcinoma and five patients having predominant lymphoepithelioma-like carcinoma, who all showed no evidence of disease (NED) (272 months). In contrast, the two patients with focal lymphoepithelioma-like carcinoma succumbed to metastatic disease 6 and 84 months after diagnosis. Similarly, all three patients in the study by Holmang et al with focal lymphoepithelioma-like carcinoma died of the disease (9-68 months), compared to none of the six patients with pure or predominant lymphoepithelioma-like carcinoma (13 months-18 years). In the current study, there were no differ- ences in prognosis between pure and mixed lymphoepithelioma-like carcinoma, although only a few of the pure lymphoepithelioma-like carcinoma cases were treated with chemotherapy.

There are no clear guidelines for the treatment of lymphoepithelioma-like carcinoma of the urinary bladder. It has been suggested that pure/predominant lymphoepithelioma-like carcinoma responds to chemotherapy and may best be treated with bladder preservation therapy. ${ }^{1,11,12}$ In the study by Amin et $a l$, four of the pure or predominant lymphoepithelioma-like carcinomas were treated with TUR and chemotherapy and all showed NED. Only two patients received chemotherapy in the study by Beltran et al and both showed NED at 21 and 47 months. In the current study, of the three pure lymphoepithelioma-like carcinoma cases treated by chemotherapy, two were free of disease at 4 and 65 months and the third had recurrent disease at 17 months. However, we also had two patients with pure lymphoepithelioma-like carcinoma with T1 disease treated by TUR only without any chemotherapy who showed NED at 38 months and 48 months.

It has been proposed that lymphoepithelioma-like carcinoma has a relatively favorable prognosis when in pure or predominant forms with reported rates of metastasis ranging from only 12 to $15 \% .^{1,5,11,12}$ The majority of our cases of lymphoepithelioma-like carcinoma at presentation were stage $\mathrm{T} 2$ or higher $(77 \%)$. In cases treated with cystectomy, the overall 5-year actuarial recurrence-free risk was 59\% (62 and $57 \%$, for pure and mixed lymphoepitheliomalike carcinoma, respectively). In a long-term study on 1054 stage T2 and T3 conventional bladder cancer patients treated by cystectomy, Stein ${ }^{20}$ reported that the 5-year recurrence-free risk was $68 \%$, which is similar to the findings in our current study for lymphoepithelioma-like carcinoma. The current study demonstrates that lymphoepithelioma-like carcinoma treated by cystectomy has a similar prognosis to ordinary urothelial carcinoma and does not differ between pure and mixed cases. The current study also adds to the sparse data in the literature regarding the prognosis of pure lymphoepithelioma-like carcinoma treated by chemotherapy. Given the association of lymphoepitheliomalike carcinoma with urothelial carcinoma in $47 \%$ of our cases and urothelial carcinoma's propensity for multifocality, partial cystectomy would typically be ill advised for lymphoepithelioma-like carcinoma.

\section{References}

1 Amin MB, Ro JY, Lee KM, et al. Am J Surg Pathol 1994;18:466-473.

2 Butler AE, Colby TV, Weiss LM, et al. Lymphoepithelioma-like carcinoma of the lung. Am J Surg Pathol 1989;13:632-639. 
3 Chen K, Chiang H, Fang C. EBER expression of pure urinary bladder lymphoepithelioma-like carcinoma in two unique Asian patients. Urol Int 2005;74:280-282.

4 Cho HJ, Kim JY, Yoo J, et al. Gastric carcinoma with lymphoid stroma. Incidence of EBV and Helicobacter pylori infection. Appl Imm Mol Morph 2003;11: 149-152.

5 Cohen RJ, Stanley JC, Dawkins HJS. Lymphoepitheliomalike carcinoma of the renal pelvis. Pathology 1999; 31:434-435.

6 Hartman CA, Roth C, Minck C, et al. Thymic carcinoma. Report of five cases and review of the literature. J Cancer Res Clin Oncol 1990;116:69-82.

7 Holmang S, Borghede G, Johansson SL. Bladder carcinoma with lymphoepithelioma-like differentiation: a report of 9 cases. J Urol 1998;159:779-782.

8 Izquierdo-Garcia FM, Garcia-Diez F, Fernandez I, et al. Lymphoepithelioma-like carcinoma of the bladder: three cases with clinicopathologic and p53 protein expression study. Virchow Arch 2004;444:420-425.

9 Kuo T, Hsueh C. Lymphoepithelioma-like salivary gland carcinoma in Taiwan: a clinicopathologic study of nine cases demonstrating a strong association with Epstein-Barr virus. Histopathology 1997;31:75-82.

10 Leyvraz S, Henle W, Chahinian AP, et al. Association of Epstein-Barr virus with thymic carcinoma. N Engl J Med 1985;312:1296-1299.

11 Lopez-Beltran A, Luque RJ, Vicioso L, et al. Lymphoepithelioma-like carcinoma of the urinary bladder: a clinicopathologic study of 13 cases. Virchow Arch 2001;438:552-557.

12 Porcaro AB, Gilioli E, Migliorini F, et al. Primary lymphoepithelioma-like carcinoma of the urinary bladder: report of one case with review and update of the literature after a pooled analysis of 43 patients. Int Urol Nephrol 2003;35:99-106.

13 Takeuchi H, Fujita H, Iwasaki F, et al. A case of Epstein-Barr virus (EBV)-associated thymic carcinoid and investigation of existence of EBV-infected cells in thymus and thymic tumors. J Clin Microbiol 2004;42: 2850-2854.

$14 \mathrm{Wu} \mathrm{MS}$, Shun C, Wu C, et al. Epstein-Barr virusassociated gastric carcinomas: relation to $H$. pylori infection and genetic alterations. Gastroenterology 2000;118:1031-1038.

15 Young RH, Eble J. Unusual forms of carcinoma of the urinary bladder. Hum Pathol 1991;22:948-965.

16 Gulley ML, Amin MB, Nicholls JM, et al. Epstein-Barr virus is detected in undifferentiated nasopharyngeal carcinoma but not in lymphoepithelioma-like carcinoma of the urinary bladder. Hum Pathol 1995;26: 1207-1213.

17 Gulley ML, Burton MP, Allred DC, et al. Epstein-Barr virus is associated with p53 accumulation in nasopharyngeal carcinoma. Hum Pathol 1998;29:252-259.

18 Chen W, Cooper NR. Epstein-Barr virus antigen 2 and latent membrane protein independently transactivate p53 through induction of NF-kB activity. J Virol 1996; 70:4849-4853.

19 Niemhom S, Kitazawa S, Murao S, et al. Co-expression of p53 and bcl-2 may correlate to the presence of Epstein-Barr virus genome and expression of proliferating cell nuclear antigen in nasopharyngeal carcinoma. Cancer Lett 2000;160:199-208.

20 Stein JP, Lieskovsky G, Cote R, et al. Radical cystectomy in the treatment of invasive bladder cancer: long term results in 1054 patients. J Clin Oncol 2001;19: 666-675. 